\title{
He is "of Two Minds about it"-A Brief Comment on Stopping by Woods on a Snowy Evening
}

\author{
Baohua Qiu \\ Putuo Branch School, Shanghai TV University, Shanghai, China \\ Email: tomasqiu@sina.com
}

\begin{abstract}
Stopping by Woods on a Snowy Evening is one of the most popular poems of Robert Frost. In this poem, in vivid description and beautiful language, the poet made the persona in a kind of dilemma between beauty("The woods are lovely, dark and deep") and obligation "But I have promises to keep," which is a conflict between the enjoyment of beauty and the practical pressures of everyday for everybody. That partly explains why people like this poem so much.
\end{abstract}

Index Terms - persona, beauty, ambivalent

Robert Frost (1874-1963)---a poet of dignity, simplicity, and ambiguity---has proved to be one of the most popular American poets of the $20^{\text {th }}$ century. A four time winner of the Pulitzer Prize, Frost received special recognition by Congress in 1960 and the following January, at age 86, had the honor of reciting at President John F. Kennedy's inauguration.

At the outbreak of World War I, Frost went back to farming in New Hampshire. Thereafter, although he made many journeys and frequent visits elsewhere, he considered the farm his home and its activities remained the focus of his poetry.

Frost's verse became part of a great tradition, shaped by Roman poet Vergil, of what is called bucolic poetry---poetry about farming. However, though he used farm situation in much of his poetry, he gave them a wide application. He might write about stepping on a rake and describe the feeling when it hit him, but he used the incident to show how life gives us bruises. Just as he wrote in the preface of his "Collected Poems", a poem should "begins in delight, and ends in wisdom." The following is a good example:

\section{Stopping by Woods on a Snowy Evening}

Whose woods these are I think I know.

His house is in the village though;

He will not see me stopping here

To watch his woods fill up with snow.

My little horse must think it queer

To stop without a farmhouse near

Between the woods and frozen lake

The darkest evening of the year.

He gives his harness bells a shake

To ask if there is some mistake.

The only other sound's the sweep

Of easy wind and downy flake.

The woods are lovely, dark and deep,

But I have promises to keep,

And miles to go before I sleep,

And miles to go before I sleep.

This is one of the most popular among Frost's popular poems. In the poem the persona who stopped by woods on a snowy evening and his feeling at the moment are vividly described. The horse felt puzzled when stopped at the moment, but he didn't know it was the beauty and darkness of the woods that attracted the master. The persona (or the " $I$ " of the poem) cherished a deep love for nature, and when surrounded by nature, he felt perfectly contented. Probably he longed to die there, being lost in the bosom of nature. Thinking of the promises to keep, he felt obliged to go, to cover the long 
distance lies before him.

But if the reader believes that all this poem "says" is all the above, and nothing more, he will surely miss some of the power of the poem. In a poetry class, he might be asked, for example, what the owner of the house, the horse, and the promises contribute to the poem. The discussion of the poem that followed such questions would be sure to astound him. First of all, the reader might try to establish why the persona stopped; in abstract terms it could only be to enjoy the beauty of the scene ("The woods are lovely, dark and deep"). There might be the suggestion that this is a special kind of beauty _ the transformation of the familiar — which would explain the persona's mentioning that he knew, or thought he knew, the owner. Why is it important that the owner will not see the persona watching the woods fill up with snow? Surely he would not object merely on the grounds of trespassing. Perhaps because the owner, like the horse, would "think it queer" for someone to sit out in the cold and watch the snow. And that brings up the horse. He is the practical one; there is no sense to stopping far from a farmhouse on a cold dark night; his "protest" — the jangling harness bells — is the only sound interrupting the soft silence of the scene. Then there is another interruption the recollection of the promises, the obligations, probably, of everyday affairs — and the practical recognition of the miles there are yet to go. So the "meaning" of the poem somehow involves a conflict between the enjoyment of beauty and the practical pressures of everyday lift. But someone at this point would be bound to bring up the last clause, "before I sleep", and that forces a re-examination of the abstraction "beauty". It is obvious that the persona is not speaking about beauty in general, but about this particular kind of experience: the woods are not only "lovely" but "dark and deep. (This is the kind of distinction we had in mind before when said that poetry was concrete and "ideas" abstract, so that poems could not be reduced to ideas. ) There is a definite suggestion in the poem that "sleep" is somehow allied to this experience in the woods. It offers, of course, an escape also from everyday pressures, but there seems to be an even more complete identification (remember "dark and deep"), so that the beauty of this moment and the beauty of sleep are united. (Someone is even likely to say this is suggested in the sleepy repetition of the next to the last line.)

Is that all the poem about? Shall we stop our analysis here? If yes, we might still feel unsatisfied. Frost himself used to define poetry as what gets left out in a translation and I quite agree with him on the point that poetry is something more than a summary, a paraphrase, a translation. Much more. So let's have a closer look and see if we can find something more in (and between) the lines.

In the first line-“"Whose woods these are I think I know."---Frost turn normal word order around. Ordinary word order would have us say something like "I think I know whose woods these are. " By moving woods to the start of the sentence, Frost gives it more prominence or power. In the second line, "His house is in the village though;" the last word make no logical sense on the surface meaning because "though" should make some contradiction to the statement before. So though here qualifies something left out As the stanza ends we learn something besides the speaker's embarrassment; we learn his motive for stopping: "To watch his woods fill up with snow." Frost's language here is plain. Saying fill up contribute to the image made by the poet; his woods becomes a container which snow can fill.

In the second stanza, picking up the here rhyme, tell us that the little horse must think it queer. Consider the word must in the line. We only claim that something must be true if we don't know it for certain. When Frost writes " $M y$ little horse must think it queer," he uses the doubtful must because he knows a human cannot mindread his horse. The persona attributes doubts to his horse because he himself believes it weird or eccentric to stop one's horse for no good reason out in the middle of nowhere to watch snow falling in the darkness. This man's uneasiness shows in his self-mockery: even his horse must think he's crazy. As the stanza continues, the poet gives us more information in images that carry feeling. The road, we learn, passes between the woods and the frozen lake. Sometimes an image informs us by what it omits. While frozen adds cold to the poem, the line also increases the solitude of the scene: the lane runs between wood and lake only, no houses or factories here, no inns or filling stations, just these cold and natural things, on "The darkest evening of the year."

In the third stanza, the little horse does what horses do; he shudders or shakes, standing still in the cold night, and to the driver who still feels foolish pausing to gaze at snow in the woods, the horse's jingling harness bells seem like the horse's reproach. The jingling is another image---so far we've had images of sight (to watch), of touch (frozen lake), and of sound (bells)---and now the sound image multiply: " the sweep/ Of easy wind and downy flake." Notice that images often appeal to more than one sense. If frozen is an image of cold in frozen lake, it is an image of sight also, because we know what a frozen lake looks like. And the sweep is a swooshing sound, but it's also a visual broom moving. By the end of the third stanza the poem has created a dramatic conflict, like a story or o play. The conflict lives in the mind of the speaker, who attributes one sides of his feeling to his horse; of course, it is the persona who thinks it queer to pause where he pauses; at the same time it is the speaker who stops to gaze into the lovely beauty of the wood, exercising the other side of his feeling. According to an old saying, he is "of two minds about it," In the final stanza, mind 1 writes the first line and mind 2 answers with the second, third and fourth; the mind with the most lines has the last word.

In our daily life, we are often ambivalent --- of two minds, sometimes of three or more--- about what we do. Often two desires are in conflict; the woods are lovely, but I have duties; the scoop of ice cream will taste good, but I will get fat; I want to see this movie, but I want to pass the test. Human beings are ambivalent by nature: we often find ourselves headed in two directions at the same time. In our deepest selves we are never one-hundred percent of anything, neither loving nor hating, and if we tell ourselves we are pure, we fool ourselves. That partly explains why people like this 
poem so much.

\section{REFERENCES}

[1] Donald Hall, (1987). To Read Literature, Holt, Rinchard and Winston, Inc.

[2] Jerome Beaty \& William H. Matchett, (1965). Poetry from statement to meaning, Oxford University Press

[3] Marcus Cunliffe, (1985).American Literature, Translation and Publishing House of China

[4] Ding Wangdao, Zhu Qing. (1989). A Guide to English Poetry, Shanghai Translation Publishing House

[5] Yang Jincai , Yu Jianhua.(1996).British and American Poetry: Poems and Criticisms Shanghai ForeignLanguages Education Press

[6] Liu Haiping, Wang Shouren, Zhu Gang.(2001). New Edition of History of American Literature. Shanghai Foreign Languages Education Press

Baohua Qiu was born in Shanghai, China, in 1951. He received his post graduate study certificate from Shanghai Foreign Studies University, China in 2000.

$\mathrm{He}$ is currently an Associate Professor in Putuo Branch School, Shanghai TV University, Shanghai, China. His research interests include teaching methodology of oral English and literature of English language. 